\title{
Replacement of corn grain by brown rice grain in dairy cow rations: Nutritional and productive effects
}

\author{
R.B. Scheibler ${ }^{a}, *$, J. Schafhäuser ${ }^{b}$, F.A. Rizzo ${ }^{a}$, J.L. Nörnberg ${ }^{c}$, D.P. Vargas ${ }^{c}$, \\ J.L.S. Silva ${ }^{\mathrm{b}}$, A.C. Fluck ${ }^{\mathrm{a}}$, V.I. Fioreze ${ }^{\mathrm{a}}$ \\ a Department of Animal Science, Agronomy College, Federal University of Pelotas, Pelotas, RS 96010-900, Brazil \\ b EMBRAPA - Brazilian Agricultural Research Corporation, Pelotas, RS 96010-971, Brazil \\ c Department of Science and Food Technology, Federal University of Santa Maria, Santa Maria, RS 97105-900, Brazil
}

\section{A R T I C L E I N F O}

\section{Article history:}

Received 13 January 2015

Received in revised form 13 July 2015

Accepted 15 July 2015

Available online $\mathrm{xxx}$

\section{Keywords:}

Alternative feed

Brown rice

Digestibility

Energy balance

Energy feedstuff

Feed efficiency

Feed intake

Milk composition

Milk yield

\begin{abstract}
A B S T R A C T
The use of brown rice grain as corn grain replacer in dairy cow diets was investigated. The following treatments were evaluated: zero, 33,63 , and $100 \%$. The experimental diets were iso in protein, energy and fiber levels. Eight multiparus Jersey cows were used. A replicated Latin square experimental design was applied. The inclusion of brown rice had no effect $(P>0.05)$ on dry mater intake and their constituents, apparent digestibility, production and milk composition, feed efficiency and blood chemistry profile. Therefore, the brown rice grain can be used replacing corn grains alternative feedstuff in dairy cow diets.
\end{abstract}

(c) 2015 Elsevier B.V. All rights reserved.

\section{Introduction}

Although rice is produced worldwide, an increase of productivity due to technology, consumption has been reduced due to changing habits of western populations. Therefore, alternative uses for rice, like their use in animal feeding, may contribute to market stability and balance of world stocks. Several studies have been carried out to evaluate rice by-products, like rice bran or defatted bran (Nörnberg, 2003) and whole plant silage (Maruyama et al., 2005). When rice is dehulled but not polished, more fat, protein and minerals are maintained and, for that the nutritional value is similar to corn grain (Table 2). Nevertheless, there are no results for the use of brown rice in animal feeding. Thus, the use of brown rice grain in animal feed may represent an important alternative for integrated crop and livestock production systems, contributing to balance and improve the productivity of agribusiness.

Abbreviations: SCC, somatic cell count; SCE, somatic cells score; DM, dry matter; OM, organic matter; CP, crude protein; EE, ether extract; ADFom, insoluble acid detergent fiber corrected for ash; aNDFom, insoluble neutral detergent fiber corrected for ash; ADL, acid detergent lignin; Cr, chrome; NFC, non-fibrous carbohydrates; DE, digestible energy; ME, metabolizable energy; NEl, net energy oflactation; NEFA, non-esterified fatty acids; BW, body weight; ECM, energy corrected milk; FE, feed efficiency.

* Corresponding author.

E-mail address: rudolf_brand@hotmail.com (R.B. Scheibler). 
We hope to define the basis to include brown rice in dairy cattle feeding, and then the option for that usage will be determined by the price relationship between it and the other grains. The objective of this study was to evaluate the inclusion of brown rice grain replacing corn grain in dairy cow diets, measuring production and milk composition, feed intake, digestibility, feed efficiency and blood parameters.

\section{Material and methods}

\subsection{Animals and location}

The experiment was carried out between September and December, 2012, in the experimental farm of Brazilian Agricultural Research Corporation (EMBRAPA), located in Capão do Leão ( $31^{\circ} 52^{\prime} 20^{\prime \prime}$ South latitude and 52 $21^{\prime} 24^{\prime \prime}$ West longitude), Rio Grande do Sul, Brazil. Milk component and chemical analyses were carried in Embrapa laboratories, at that experimental station. The work was carried out in accordance with the Ethics Committee of Federal University of Pelotas, Brazil, registered under protocol 4844.

Eight cows with Madio weight of $379 \pm 28 \mathrm{~kg}$ and milk production of $20 \pm 2 \mathrm{~kg}$ between second and fourth lactation, were housed in free stall and adapted to the experimental diets for 15 days before the start of the experiment. They had free access to drinking water.

\subsection{Treatments and experimental diets}

Replacement levels of corn by rice were zero, 33, 63.67, and 100\%. The experimental diets (Table 1) were formulated to reach the same levels of energy, crude protein and neutral detergent fiber (Table 2), according to NRC (2001) profiles. The

Table 1

Diets composition.

\begin{tabular}{|c|c|c|c|c|}
\hline \multirow[t]{2}{*}{ Ingredients (g/kg of DM) } & \multicolumn{4}{|c|}{ Treatment } \\
\hline & Ro & R33 & R63 & R100 \\
\hline Forage $^{\mathrm{a}}$ & 524.2 & 520.3 & 523.6 & 515.1 \\
\hline Concentrate & 475.8 & 479.7 & 476.4 & 484.9 \\
\hline Corn, grain & 357.1 & 239.6 & 130.0 & - \\
\hline Brown rice, grain & - & 120.5 & 227.8 & 364.3 \\
\hline Soybean, meal & 102.4 & 103.2 & 102.3 & 104.0 \\
\hline $\mathrm{NaCl}$ & 1.6 & 1.6 & 1.6 & 1.7 \\
\hline Mineral - vitamin ${ }^{\mathrm{b}}$ & 13.2 & 13.3 & 13.1 & 13.4 \\
\hline Dicalcium phosphate & 1.5 & 1.6 & 1.5 & 1.6 \\
\hline
\end{tabular}

$\mathrm{R} 0=$ without rice inclusion; $\mathrm{R} 33=33.46 \%$ rice; $\mathrm{R} 63=63.67 \%$ rice; $\mathrm{R} 100=100 \%$ rice replacing corn.

a Mixture of corn silage $487 \mathrm{~g} / \mathrm{kg}$ of mixture, the remainder being alfalfa hay, on a dry mater basis.

b Minimum composition per kg: Ca - 229 g; P - 95g; Mg - 1.1g; Na - 60g; S - 12g; Vit. A - 120,000 UI; Vit. D3 - 30,000 UI; Vit. E - 1200 UI; Se - 20g; Zn - 3g; Lasalocid - $1000 \mathrm{mg}$.

Table 2

Chemical composition of the diets and ingredients.

\begin{tabular}{|c|c|c|c|c|c|c|c|}
\hline & \multirow{2}{*}{$\begin{array}{l}\text { DM } \\
\mathrm{g} / \mathrm{kg}\end{array}$} & \multirow{2}{*}{$\begin{array}{l}\text { OM } \\
\text { g/kg DM }\end{array}$} & $\mathrm{CP}$ & $\mathrm{EE}$ & aNDFom $^{\mathrm{b}}$ & NFC & \multirow{2}{*}{$\begin{array}{l}\mathrm{NEl} \\
\mathrm{MJ} / \mathrm{kg} \mathrm{OM}\end{array}$} \\
\hline & & & \multicolumn{4}{|c|}{$\mathrm{g} / \mathrm{kg} \mathrm{OM}$} & \\
\hline \multicolumn{8}{|l|}{ Diets } \\
\hline R0 & 474.9 & 927.3 & 184.6 & 30.9 & 338.0 & 427.0 & 7.1 \\
\hline R33 & 476.1 & 927.9 & 184.2 & 30.0 & 335.1 & 430.0 & 7.2 \\
\hline R63 & 483.7 & 928.5 & 184.0 & 29.9 & 334.5 & 431.5 & 7.1 \\
\hline R100 & 482.8 & 927.7 & 184.0 & 28.8 & 329.0 & 437.5 & 7.2 \\
\hline \multicolumn{8}{|l|}{ Ingredients } \\
\hline Corn, silage & 223.8 & 931.9 & 93.8 & 38.1 & 652.9 & 215.2 & 6.3 \\
\hline Alfafa, hay & 812.2 & 896.1 & 239.9 & 34.9 & 481.8 & 243.4 & 5.8 \\
\hline Corn, grain & 810.7 & 979.1 & 91.3 & 31.7 & 88.19 & 749.4 & 8.6 \\
\hline Brown rice, grain & 848.1 & 984.1 & 89.7 & 27.7 & 77.37 & 765.2 & 8.7 \\
\hline Soybean, meal & 849.5 & 932.7 & 605.4 & 22.4 & 161.9 & 210.2 & 10.7 \\
\hline $\mathrm{NaCl}$ & 985.4 & 28.0 & - & - & - & - & - \\
\hline Mineral - vitamin ${ }^{\mathrm{a}}$ & 956.4 & 135.3 & - & - & - & - & - \\
\hline Dicalcium phosphate & 931.9 & 94.0 & - & - & - & - & - \\
\hline
\end{tabular}

$\mathrm{R} 0$ = without rice inclusion; $\mathrm{R} 33$ = 33.46\% rice; $\mathrm{R} 63=63.67 \%$ rice; $\mathrm{R} 100=100 \%$ rice replacing corn.

a Composição mínima por kg: Ca - 229g; P - 95g; Mg - 1.1g; Na - 60g; S - 12g; Vit. A - 120,000 UI; Vit. D3 - 30,000 UI; Vit. E - 1200 UI; Se - 20 g; Zn $3 \mathrm{~g}$; Lasalocida - $1000 \mathrm{mg}$.

b Neutral detergent fiber using a heat stable amylase and corrected for ash, without the use of sodium sulfite. 
rice used was "BRS Querência," a long-light grain type, developed by EmbrapaGenetic Improvement Program, which was dried and dehulled in a industrial plant.

The forage portion was a mix (1/1) of corn silage and chopped alfalfa hay, fed twice a day, at 7 and $19 \mathrm{~h}$, calculated to reach $10 \%$ of orts. The concentrate portion was fed three times a day ( $7 \mathrm{~h}, 13: 30 \mathrm{~h}$ and $19 \mathrm{~h}$ ) separately, to ensure total intake.

\subsection{Experimental management}

Every experimental period was 15 days, being 10 days to adapt the animals to the treatments and the others five days to the collection period, when the feeds were sampled and stored in a freezer $\left(-20^{\circ} \mathrm{C}\right)$ to do a composite sample by each period. At each morning, before the next meal, orts were weighed and samples collected and stored to analyze the chemical composition. At the end of each period, the feeds and orts samples were mixed to obtain pooled samples.

The fecal production was estimated by supplying $5 \mathrm{~g}$ of chromium $\left(\mathrm{Cr}_{2} \mathrm{O}_{3}\right)$ twice daily after milking. Fecal samples were collected directly from the rectum or voluntary evacuation, twice daily, before milking, during the five days for data collection, these were placed in plastic bags and stored in a freezer $\left(-20^{\circ} \mathrm{C}\right)$. At the end of each collection period, has obtained a sample pooled by period by animal.

Blood was collected by venipuncture of the jugular vein on days 14 and 15 of each experimental period. Samples were collected in vacutainer tubes. The samples were kept at rest for $10 \mathrm{~min}$, and then centrifuged at $8000 \mathrm{rpm}$ for $10 \mathrm{~min}$ immediately after, they were placed in isothermal box, and sent for analysis at commercial laboratory.

Milk samples of two consecutive milkings (morning and afternoon) of all experimental animals were collected on days 14 and 15 of each period, and mixed according to milk production. Samples were placed in tubes, containing bronopol (2-bromo-2-nitro-1,3-propanediol) refrigerated, and sent to the laboratory within $24 \mathrm{~h}$.

\subsection{Evaluations}

Milk production was measured by the average milk yield, per cow, on five days of each collection period, the value was corrected for energy (ECM) according to the equation described by Sjaunja et al. (1990).

Milk components (fat, protein, lactose, and total solids) were determined by infrared spectroscopy, according to the AOAC (1996, method 972.16).

Somatic cells count (CCS) was determined by flow cytometry, and the values were processed according to the methodology described by Shook (1993) when the somatic cells score $(\mathrm{ECS})=[\log 2(\mathrm{SCC} / 100)]+3$.

Dry matter (DM), organic matter (OM), crude protein (CP), and ether extract (EE) were determined according to the AOAC (1996, methods 967.03, 942.05, 954.05 and 920.39, respectively). The insoluble acid detergent fiber corrected for ash (aADFom), insoluble neutral detergent fiber corrected for ash (aNDFom), using a heat stable amylase, without the use of sodium sulfite, and acid detergent lignin (ADL) were analyzed according to Van Soest et al. (1991). The non-fiber carbohydrates (NFC) were corrected for ash and protein as proposed by Hall (2003).

For diet energy concentration and balance we used the equations described by the NRC (2001), using the apparent digestibility coefficients of this study. Values were converted in $\mathrm{MJ} / \mathrm{kg}$.

Blood metabolic profile (glucose, triglycerides and total cholesterol) were determined using automated enzymatic colorimetric method, non-esterified fatty acids (NEFA) by enzymatic spectrophotometry and blood urea by automated kinetic method according to specific protocols of commercial laboratory of Pelotas town, Brazil.

\subsection{Experimental design and statistical analysis}

A replicated $(4 \times 4)$ Latin Square experimental design, with four treatments and four periods, was applied. Animals were considered experimental units, they were distributed in the square considering its previous milk yield and parity order. Data were submitted to analysis of variance (ANOVA) and regression (linear and quadratic) using the MIXED procedure and considering animal as random effect in SAS statistical package, version 9.0 (SAS, 2002). The following causes of variation were evaluated: treatment, period, square, cow within square and the interaction square $\times$ treatment. The model applied for ANOVA was: $Y_{i j k l}=\mu+Q_{i}+T_{j}+P_{k}+Q T_{i j}+A_{(i) l}+e_{i j k}$. Where: $Y_{i j k l}=$ mean value obtained for each observation; $\mu=$ general mean of the variable in the experiment; $Q_{i}=$ effect of the square, where $i=1$ and $2 ; T_{j}=$ effect of treatment $j$, with $j=1,2,3$ and 4 ; $P_{k}=$ effect of period, with $k=1,2,3$ and $4 ; Q T_{i j}=$ interaction between square $i$ and treatment $j ; A_{(i) l}=$ effect of cow 1 within square $i ; e_{i j k}=$ experimental error.

\section{Results and discussion}

\subsection{Feed intake}

The inclusion of brown rice did not affect intake of dry matter and their constituents ( $\mathrm{kg} / \mathrm{d})$, not even the relation to body weight (g/kg BW) (Table 3). 
Table 3

Voluntary intake of dietery components.

\begin{tabular}{|c|c|c|c|c|c|c|c|}
\hline \multirow[t]{2}{*}{ Item } & \multicolumn{4}{|c|}{ Treatment } & \multirow[t]{2}{*}{ SEM } & \multicolumn{2}{|c|}{$P$-value } \\
\hline & R0 & R33 & R63 & R100 & & Linear & Quadratic \\
\hline DM (kg/d) & 18.2 & 18.0 & 18.2 & 17.9 & 0.29 & 0.57 & 0.75 \\
\hline DM (g/kg of BW) & 45.6 & 45.8 & 46.5 & 45.6 & 0.06 & 0.86 & 0.64 \\
\hline $\mathrm{OM}(\mathrm{kg} / \mathrm{d})$ & 16.8 & 16.74 & 16.9 & 16.6 & 0.29 & 0.66 & 0.77 \\
\hline OM (g/kg of BW) & 42.3 & 42.5 & 43.2 & 42.4 & 0.04 & 0.81 & 0.65 \\
\hline aNDFom $(\mathrm{kg} / \mathrm{d})$ & 5.71 & 5.62 & 5.66 & 5.48 & 0.32 & 0.50 & 0.84 \\
\hline aNDFom ( $\mathrm{g} / \mathrm{kg}$ of BW) & 14.3 & 14.3 & 14.4 & 14.0 & 0.07 & 0.70 & 0.72 \\
\hline $\mathrm{CP}(\mathrm{kg} / \mathrm{d})$ & 3.11 & 3.08 & 3.11 & 3.06 & 0.03 & 0.44 & 0.77 \\
\hline $\mathrm{EE}(\mathrm{kg} / \mathrm{d})$ & 0.51 & 0.50 & 0.50 & 0.48 & 0.02 & 0.06 & 0.80 \\
\hline $\mathrm{NFC}(\mathrm{kg} / \mathrm{d})$ & 7.18 & 7.20 & 7.28 & 7.27 & 0.15 & 0.43 & 0.86 \\
\hline
\end{tabular}

$\mathrm{R} 0=$ without rice inclusion; $\mathrm{R} 33$ = 33.46\% rice; $\mathrm{R} 63=63.67 \%$ rice; $\mathrm{R} 100=100 \%$ rice replacing corn.

$\mathrm{DM}$, dry matter; OM, organic matter; CP, crude protein; EE, ether extract; aNDFom, insoluble neutral detergent fiber corrected for ash, using a heat stable amylase without the use of sodium sulfite; NFC, non-fiber carbohydrates; BW, body weight.

Table 4

Effect of treatments on digestibility.

\begin{tabular}{|c|c|c|c|c|c|c|c|}
\hline \multirow[t]{2}{*}{ Item } & \multicolumn{4}{|c|}{ Treatment } & \multirow[t]{2}{*}{ SEM } & \multicolumn{2}{|c|}{$P$-value } \\
\hline & R0 & R33 & R63 & $\mathrm{R} 100$ & & Linear & Quadratic \\
\hline DM & 0.72 & 0.73 & 0.73 & 0.73 & 1.48 & 0.70 & 0.80 \\
\hline $\mathrm{OM}$ & 0.74 & 0.75 & 0.75 & 0.75 & 1.45 & 0.58 & 0.83 \\
\hline $\mathrm{CP}$ & 0.69 & 0.69 & 0.68 & 0.68 & 1.73 & 0.38 & 0.74 \\
\hline $\mathrm{EE}$ & 0.64 & 0.64 & 0.66 & 0.66 & 3.88 & 0.59 & 0.95 \\
\hline aNDFom & 0.55 & 0.56 & 0.55 & 0.56 & 1.95 & 0.57 & 0.86 \\
\hline NFC & 0.91 & 0.90 & 0.92 & 0.91 & 1.27 & 0.75 & 0.86 \\
\hline
\end{tabular}

$\mathrm{R} 0=$ without rice inclusion; $\mathrm{R} 33=33.46 \%$ rice; $\mathrm{R} 63=63.67 \%$ rice; $\mathrm{R} 100=100 \%$ rice replacing corn.

DM - dry matter; OM - organic matter; CP - crude protein; EE - ether extract; aNDFom - insoluble neutral detergent fiber corrected for ash, using a heat stable amylase without the use of sodium sulfite; NFC - non-fiber carbohydrates.

Using an equation to predict dry matter intake as described by the NRC (2001), estimates of $17.65 \mathrm{~kg} / \mathrm{day}$ ( $44.6 \mathrm{~g} / \mathrm{kg} \mathrm{BW}$ ) was obtained that was lower than observed intake of this study. According to Van Soest (1994), these aspects may be related to proper feed management and good quality feeds. Fiber intake was also higher than predicted by the NRC (2001) of 10 and $13 \mathrm{~g} / \mathrm{kg}$ BW. The average value observed $(14.2 \mathrm{~g} / \mathrm{kg} \mathrm{BW})$ shows that the concentration and fiber did not limit DM intake. According to Allen (2000), dietary NDF is a major factor of feed intake regulation. Other factors that may contribute to DMI and NDFom intake were higher than the estimates, and they would be the particle size of hay increasing the feed flow and high concentrate levels in the diet. Although there was no effect on NFC intake $(P=0.1042)$, there was a tendency for that due to the NFC concentration in rice being higher than corn. Therefore, could be acidosis, but it not happened, probably because the NFC levels were within the limits suggested by NRC (2001), that suggest NFC concentrations between 330 and $420 \mathrm{~g} / \mathrm{kg}$ DM.

\subsection{Apparent digestibility}

Diet digestibility was affected by the replacement of corn by brown rice $(P>0.05)$ for DM, OM, CP, EE, aNDFom and NFC (Table 4). This supports that small nutritional differences in the energy sources studied are not able to worsen the performance of dairy cows. Since digestibility of DM and aNDFom may affect intake, it would explain the high dry matter intake, showed earlier. According to Paterson et al. (1994), dry matter digestibility more than $660 \mathrm{~g} / \mathrm{kg}$, can reduce the rumen fill and improve the ruminal turn over, thus increasing intake.

\subsection{Production and milk composition, feed efficiency and energy balance}

Milk yield ( $\mathrm{kg} / \mathrm{d}$ ), energy corrected milk yield (ECM kg/d), milk composition ( $\mathrm{g} / \mathrm{kg}$ and $\mathrm{kg} / \mathrm{d}$ ), feed efficiency ( $\mathrm{FE}, \mathrm{kg} \mathrm{ECM} / \mathrm{kg}$ $\mathrm{MO})$ and energy balance $(\mathrm{BE}, \mathrm{MJ} / \mathrm{d})$ were not influenced $(P>0.05)$ by the replacement of corn by brown rice (Table 5$)$. These results were similar to that reported by Nörnberg (2003) and López et al. (2007), using the same control diets, based on corn and soybean meal, with Jersey cows at the same experimental station. These similar production levels may be indicative that the homeostasis of animals was preserved and some little differences between corn and rice were not sufficient to induce any effects. 
Table 5

Effect of treatments on milk production and energy balance.

\begin{tabular}{|c|c|c|c|c|c|c|c|}
\hline \multirow[t]{2}{*}{ Item } & \multicolumn{4}{|c|}{ Treatment } & \multirow[t]{2}{*}{ SEM } & \multicolumn{2}{|c|}{$P$-value } \\
\hline & Ro & R33 & R63 & R100 & & Linear & Quadratic \\
\hline Milk yield (kg/d) & 22.1 & 22.1 & 22.0 & 21.7 & 0.35 & 0.68 & 0.82 \\
\hline $\mathrm{ECM}(\mathrm{kg} / \mathrm{d})$ & 24.7 & 24.4 & 24.6 & 24.3 & 0.64 & 0.75 & 0.98 \\
\hline $\mathrm{FE}(\mathrm{kg} \mathrm{ECM} / \mathrm{kg} \mathrm{MO})$ & 1.46 & 1.46 & 1.46 & 1.46 & 0.03 & 0.91 & 0.88 \\
\hline Energy balance & 20.4 & 21.8 & 21.9 & 21.1 & 3.83 & 0.84 & 0.64 \\
\hline \multicolumn{8}{|l|}{ Milk fat } \\
\hline $\mathrm{g} / \mathrm{kg}$ & 47.3 & 46.6 & 47.7 & 47.3 & 0.12 & 0.85 & 0.92 \\
\hline $\mathrm{kg} / \mathrm{d}$ & 1.05 & 1.03 & 1.05 & 1.03 & 0.03 & 0.85 & 0.89 \\
\hline \multicolumn{8}{|l|}{ Milk protein } \\
\hline $\mathrm{g} / \mathrm{kg}$ & 37.8 & 37.2 & 36.9 & 37.8 & 0.07 & 0.91 & 0.21 \\
\hline $\mathrm{kg} / \mathrm{d}$ & 0.83 & 0.82 & 0.81 & 0.82 & 0.02 & 0.61 & 0.67 \\
\hline \multicolumn{8}{|l|}{ Lactose } \\
\hline $\mathrm{g} / \mathrm{kg}$ & 46.2 & 46.2 & 46.4 & 46.4 & 0.03 & 0.69 & 0.98 \\
\hline $\mathrm{kg} / \mathrm{d}$ & 1.02 & 1.02 & 1.02 & 1.01 & 0.02 & 0.73 & 0.82 \\
\hline \multicolumn{8}{|l|}{ Total solids } \\
\hline $\mathrm{g} / \mathrm{kg}$ & 143.7 & 141.1 & 142.5 & 143.2 & 0.16 & 0.99 & 0.19 \\
\hline $\mathrm{kg} / \mathrm{d}$ & 3.17 & 3.11 & 3.14 & 3.11 & 0.07 & 0.66 & 0.89 \\
\hline $\mathrm{SCC}^{\mathrm{a}}$ & 90.9 & 82.3 & 78.0 & 94.8 & 0.47 & 0.93 & 0.70 \\
\hline
\end{tabular}

$\mathrm{R} 0=$ without rice inclusion; $\mathrm{R} 33=33.46 \%$ rice; $\mathrm{R} 63=63.67 \%$ rice; $\mathrm{R} 100=100 \%$ rice replacing corn.

$\mathrm{ECM}$ - energy corrected milk = kg milk $\times((383 \mathrm{fat} \%+242$ protein\% + 165.4 lactose\% + 20.7)/3140) (Sjaunja et al., 1990). FE - feed efficiency .

a (Somatic cell count $\times 1000) / \mathrm{mL}$, values of the data changed according to Shook $(1993)$ in which somatic cells score $($ SCE $)=[\log 2($ SCC $/ 100)]+3$.

Table 6

Effect of dietary treatments on blood parameters.

\begin{tabular}{|c|c|c|c|c|c|c|c|}
\hline \multirow[t]{2}{*}{ Item } & \multicolumn{4}{|c|}{ Treatment } & \multirow[t]{2}{*}{ SEM } & \multicolumn{2}{|c|}{$P$-value } \\
\hline & R0 & R33 & R63 & R100 & & Linear & Quadratic \\
\hline Glucose $(\mathrm{mg} / \mathrm{dL})$ & 61.3 & 61.3 & 61.3 & 61.2 & 1.40 & 0.97 & 0.93 \\
\hline Triglicerides (mg/dL) & 2.5 & 2.4 & 2.6 & 2.2 & 0.25 & 0.31 & 0.28 \\
\hline Blood urea $(\mathrm{mg} / \mathrm{dL})$ & 36.9 & 35.0 & 36.4 & 34.9 & 1.63 & 0.41 & 0.87 \\
\hline Cholesterol (mg/dL) & 160.9 & 165.6 & 159.9 & 152.6 & 6.51 & 0.44 & 0.51 \\
\hline $\mathrm{NEFA}(\mathrm{mmol} / \mathrm{L})$ & 0.22 & 0.22 & 0.22 & 0.21 & 0.01 & 0.35 & 0.65 \\
\hline
\end{tabular}

$\mathrm{R} 0=$ without rice inclusion; $\mathrm{R} 33=33.46 \%$ rice; $\mathrm{R} 63=63.67 \%$ rice; $\mathrm{R} 100=100 \%$ rice replacing corn.

NEFA - non-esterified fatty acids.

\subsection{Biochemical blood profile}

No treatment effects were observed $(P>0.05)$ for glucose, triglycerides, urea, total cholesterol (mg/dL) and non-esterified fatty acids (NEFA mmol/L) serum concentrations (Table 6). These parameters were within the physiological values for cattle described by Kaneko et al. (2008) and such findings would be important to identify any physiological changes produced by replacement of dietary inputs.

\section{Conclusions}

Brown rice grain is a good alternative energy feedstuff and can be used in dairy cow diets, totally replacing corn grain, without any negative effect on the animal health, feed intake, digestibility, milk yield and composition.

\section{Acknowledgment}

The authors express their gratitude to Brazilian Agricultural Research Corporation (EMBRAPA) for funding this study.

\section{References}

Allen, M.S., 2000. Effects of diet on short-term regulation of feed intake by lactating dairy cattle. J. Dairy Sci. 83, 1598-1624. Association of Official Analytical Chemists (AOAC), 1996. Official Methods of Analysis, 16th ed. AOAC, Washington, DC, USA. Hall, M.B., 2003. Challenges with non-fiber carbohydrate methods. J. Anim. Sci. 81, 3226-3232.

. Kaneko, J.J., Harvey, J.W., Bruss, M.L. (Eds.), 2008. Clinical Biochemistry of Domestic Animals, Academic press, 6, 896p.

López, S., López, J., Junior, W.S., 2007. Milk yield and composition, and feed efficiency in Jersey cows supplemented with fat sources. Arch. Latinoam. Prod. Anim. 15, 1-9.

Maruyama, S., Yokoyama, I., Asai, H., Sakaguchi, S., Ohtani, T., Yokota, H., Kita, K., 2005. Influence of ripening stages on the quality of whole crop silage and grain silage of fodder rice. Asian Australas. J. Anim. Sci. 18, 340-344. 
Nörnberg, J.L., 2003. Efeito de diferentes fontes de gordura na dieta de vacas Jersey na fase inicial de lactação. Tese (Doutorado em Zootecnia) - UFRGS, Porto Alegre, Brasil, $174 \mathrm{p}$.

NRC (National Research Council), 2001. Nutrient Requirements of Dairy Cattle, 7th rev. ed., pp. 381.

Paterson, J.A., Belyea, R.L., Bowman, J.P., et al., 1994. The impact of forage quality and supplementation regime on ruminant animal intake and performance. In: Fahey Jr., G.C. (Ed.), Forage Quality, Evaluation and Utilization. American Society of Agronomy, Madison, pp. 59-114.

Sjaunja, L.O., Baevre, L., Junkkarinen, L., Pedersen, J., Setälä, J., 1990. A nordic proposal for an energy corrected milk (ECM) formula. In: Proceedings of the 27th Session of International Committee of Recording and Productivity of Milk Animal, France., pp. $156-157$.

Shook, G.E., 1993. Genetic improvement of mastitis through selection on somatic cell count. Vet. Clin. North Am. Food Anim. Pract. 9, $563-581$.

Statistical analysis system - SAS, 2002. The SAS System for Windows.v.9.0. SAS Institute Inc., Cary.

Van Soest, P.J., 1994. Nutritional Ecology of the Ruminant. Cornell University Press, pp. 476p.

Van Soest, P.J., Robertson, J.B., Lewis, B.A., 1991. Symposium: carbohydrate methodology, metabolism, and nutritional implications in dairy cattle. J. Dairy Sci. 74, 3583-3597. 